\title{
Editorial Note: Multimedia Systems in Fog and Mobile Edge Computing
}

Published online: 2 April 2019

(C) Springer Science+Business Media, LLC, part of Springer Nature 2019

Multimedia Tools and Applications gratefully acknowledges the editorial work of the scholars listed below on the special issue entitled, "Multimedia Systems in Fog and Mobile Edge Computing."

Of 12 papers submitted to this issue, 9 were eventually accepted after a stringent peer-review process.

\section{Schahram Dustdar}

Vienna University of Technology, Vienna, Austria

dustdar@dsg.tuwien.ac.at

\section{Yaser Jararweh (Corresponding Guest Editor)}

Carnegie Mellon University, Pittsburgh, USA

yaser.amd@gmail.com

\section{Syed Hassan Ahmed}

University of Central Florida, Florida, USA

sh.ahmed@ieee.org

\section{Jaime Lloret Mauri}

Universidad Politècnica de Valencia, Valencia, Spain

jlloret@dcom.upv.es

\section{Elhadj Benkhelifa}

Staffordshire University, Staffordshire, UK

e.benkhelifa@staffs.ac.uk

Publisher's note Springer Nature remains neutral with regard to jurisdictional claims in published maps and institutional affiliations. 